\title{
Who Owns Ocean Biodiversity?: The Legal Status and Role of Patents as a Means to Achieve Equitable Distribution of Benefits
}

Abhaya Ganashree

Follow this and additional works at: https://scholarlycommons.law.case.edu/jil

Part of the International Law Commons

\section{Recommended Citation}

Abhaya Ganashree, Who Owns Ocean Biodiversity?: The Legal Status and Role of Patents as a Means to Achieve Equitable Distribution of Benefits, 53 Case W. Res. J. Int'I L. 197 (2021)

Available at: https://scholarlycommons.law.case.edu/jil/vol53/iss $1 / 9$

This Article is brought to you for free and open access by the Student Journals at Case Western Reserve University School of Law Scholarly Commons. It has been accepted for inclusion in Case Western Reserve Journal of International Law by an authorized administrator of Case Western Reserve University School of Law Scholarly Commons. 


\title{
Who OWns OCEAN Biodiversity?: \\ The Legal Status and Role of \\ Patents as a Means to Achieve \\ Equitable Distribution of BENEFITS
}

\author{
Abhaya Ganashree*
}

Abstract

The technological race to obtain genetic material from the ocean floors has been led by the economically advanced states of the global North. It has been a race for obtaining mineral resources among states, dominated by Inter-State competition for land, people and money. However, when the issue concerns mineral resources found in areas beyond national jurisdiction (ABNJ), there is potential for either competition or cooperation among nation-states. Deep-sea mining and bioprospecting are particularly divisive. Very early on states recognised that this might lead to political tensions among them and so agreed to a standard that they would adhere to in their exploration and exploitation of these resources. This led to the creation of the 'Common Heritage of Mankind' principle. Although this agreement was reached in reference to mineral resources, the regulation of marine genetic resources (MGRs), particularly those mined from ABNJ, remains ungoverned. However, with the increasing incidence of ocean exploration, the use of these resources have exposed three gaps within the global framework of access and benefit-sharing stemming from the international law, biodiversity law and intellectual property respectively.

Starting under the premise of the public domain, resources are being appropriated under the absence of any applicable legal regime. Chapter I attempts to answer the question who owns biodiversity by identifying the regulatory gap within the Law of the Sea. Chapter II addresses the regulatory gap under biodiversity law and identifies the problem of inefficiency within the current benefit-sharing framework. The question of whether the interlinking of the patent system and biodiversity law would alleviate this inefficiency is considered and three hindrances to such an argument are identified. Chapter III considers academic, political and stakeholder opinion on these issues by taking into account international and transnational law. This thorough analysis indicated that patent law has thus far been unable to lead to

* Abhaya is an LLM Candidate at the London School of Economics and Political Science. She has an interest in public international law and dispute resolution. 
an effective and efficient solution. This paper then takes into account the existing political and stakeholder conflicts surrounding the maximisation of economic value that have so far hindered the process of reaching an efficient solution at the international arena. The author proposes that the 'nondominium' principle could prove to be an effective solution and potentially pave the way to incentivise user countries to innovate without private appropriation of rights through patents.

\section{TABle of Contents}

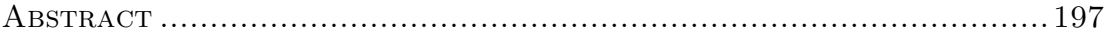

TABLE of Contents............................................................... 198

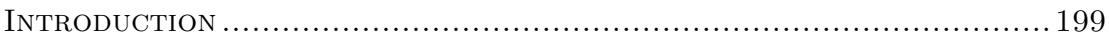

I. Legal Status of the ABNJ and Policy Background ............202

A. The Regulatory Gap - Access and Benefit Sharing of MGRs beyond

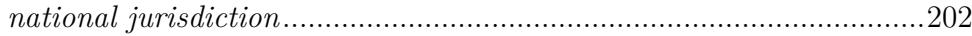

1. The UNCLOS and MGRs Common Heritage of Mankind vs Freedom of the High Seas ........................................................203

2. Political Impasse - Diverging Opinion ..........................................205

3. The Legal Status .......................................................................206

a. The Positive Approach — "As it is" .....................................206

b. The Normative Approach — 'As it should be'........................208

4. In the Interest of Science and Development ................................210

II. The Role of Patents within the Access and BenefitSHARING FRAMEWORK.

A. The Regulatory Gap - Genetic Resources Beyond National

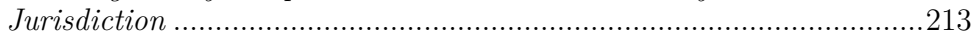

1. Biodiversity Law and MGRs ...................................................213

2. Intellectual Property Rights, ABS frameworks and MGRs...........215

3. Patentability of MGR-based inventions and processes.................216

a. Novelty, Inventive Step and Industrial Application ..................217

b. The impact of patents on the ABS Framework .......................219

4. Effectively using Patents to Improve the Efficiency of the ABS Framework

B. Hindrances to the Interlinking of the Patent System and International Biodiversity Law .....................................................222

1. Disclosure of origin requirements ..............................................222

2. Digital Sequence Information ...................................................223

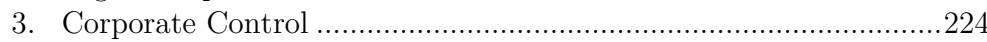

III. Towards An Effective Solution ......................................... 226

A. Mandatory Disclosure of Origin Requirement ..................................226

B. Inclusion of Digital Sequence Information......................................222

C. Overwhelming Corporate Control.......................................................2230

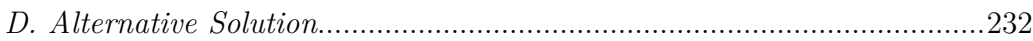

1. Application of Nondominium to ABNJ.......................................2233

2. Benefits over Current Regime ................................................2234

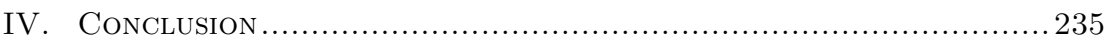




\section{INTRODUCTION}

In 1962, a green fluorescent protein, derived from a bioluminescent jellyfish, was found in the deep-sea. ${ }^{1}$ Drawing inspiration from their bright glow, in 2008, scientists won the Nobel Prize due to their discovery that the protein could be used as a biological highlighter to track the growth of cancerous cells. ${ }^{2}$ The ability of marine genetic resources ("MGRs") to thrive in harsh conditions, for example in hydrothermal vents, ${ }^{3}$ has resulted in MGRs becoming indispensable for use in the field of medicine and for future research developments. ${ }^{4}$ This is a momentous example of MGRs' value found in the areas beyond national jurisdiction ("ABNJ"), and is a testament that future is here and must be regulated. Science has become more important than ever for development, with the UNESCO Declaration on Science and the Use of Scientific Knowledge acknowledging that this was even more so for developing countries. ${ }^{5}$ The pace of such unprecedented scientific advancement has increased MGRs' significance and has created the need for equitable distribution of benefits arising from its derivatives. ${ }^{6}$ The bioprospecting process, defined as the "scientific investigation of living organisms for commercially valuable genetic and biochemical resources," includes the research, collection and utilization of genetic resources. ${ }^{7}$ While exploiting genetic resources, signatories are obligated to follow the Convention on Biological Diversity ("CBD"), ${ }^{8}$ where they have committed to the "fair and equitable sharing of the benefits arising

1. Marc Zimmer, Illuminating Disease: An Introduction to Green FLuORESCENT Proteins 1 (2015).

2. Id. at $15-17$.

3. Serge Beslier, The Protection and Sustainable Exploitation of Genetic Resources of the High Seas from the European Union's Perspective, 24 Int'L J. Marine \& Coastal L. 333, 334 (2009).

4. Angelica Bonfanti \& Seline Trevisanut, TRIPS on the High Seas: Intellectual Property Rights on Marine Genetic Resources, 37 BRook. J. INT'L L. 187, 188 (2011).

5. Declaration on Science and the Use of Scientific Knowledge, ฯ 34, UNESCO (July 1, 1999), http://www.unesco.org/science/wcs/eng/declaration_e.htm [https://perma.cc/N7VV-2KAX].

6. See Beslier, supra note 3 , at $334,336-39$.

7. Joanna Mossop, The Continental Shelf Beyond 200 Nautical Miles 111 (2016).

8. Convention on Biological Diversity, June 5, 1992, 1760 U.N.T.S. 79 [hereinafter CBD]. 
out of the utilization of genetic resources."9 Although the ABNJ, comprising of the high seas and the surrounding area, is open to all and cannot be appropriated, ${ }^{10}$ few countries have the economic resources and technical capability to conduct bioprospecting to obtain these resources..$^{11}$ However, most sampling is conducted in developing tropical countries. ${ }^{12}$ This has led to unequitable distribution, which - alongside the emerging issues surrounding intellectual property protection offered to such discoveries and inventions - has given rise to discussions in both academic and international fora. ${ }^{13}$ These discussions stem from the regulatory gap of MGRs within the ABNJ left in the United Nations Convention on the Law of the Seas ("UNCLOS") and the 1994 Implementation Agreement. ${ }^{14}$ Further, the Nagoya Protocol on Access to Genetic Resources and the Fair and Equitable Sharing of Benefits Arising from Their Utilization ("Nagoya Protocol") ${ }^{15}$ of the CBD failed to acknowledge the similar necessity to regulate the access and benefitsharing of MGRs beyond national jurisdictions. ${ }^{16}$ For more than a decade the international community has expressed differing viewpoints on this issue, ${ }^{17}$ but the question remains: how do we close such gaps in practice without hampering scientific research in the future?

Currently, MGRs are tested to treat chronic pain and asthma. ${ }^{18}$ They are also comprised of $11 \%$ of the gene bank, per a 2017 study. ${ }^{19}$

9. $\quad I d$. at art. 1 .

10. United Nations Convention on the Law of the Sea, opened for signature Dec. 10, 1982, 1833 U.N.T.S. 397, art. 136 [hereinafter UNCLOS].

11. See Rachel Wynberg, Marine Genetic Resources and Bioprospecting in the Western Indian Ocean, in REG'L State of the CoAst ReP. 407, 409 (José Paula ed., 2015).

12. Id.

13. See id. at 412 .

14. G.A. Res. 48/263, Agreement Relating to the Implementation of Part XI of the United Nations Convention on the Law of the Sea of 10 December 1982 (Aug. 17, 1994).

15. Conference of the Parties to the Convention on Biological Diversity, Protocol on Access to Genetic Resources and the Fair and Equitable Sharing of Benefits Arising from Their Utilization to the Convention on Biological Diversity, Oct. 29, 2010, U.N. Doc. $\mathrm{UNEP} / \mathrm{CBD} / \mathrm{COP} / \mathrm{DEC} / \mathrm{X} / 1$ [hereinafter Nagoya Protocol].

16. Beslier, supra note 3 , at 337 .

17. Id. at 339-40.

18. Kevin Krajick, Medicine from the Sea, Smithsonian (Apr. 30, 2004), https://www.smithsonianmag.com/science-nature/medicine-from-thesea-99586066/ [https://perma.cc/C8AZ-69S8].

19. Robert Blasiak et al., Corporate Control and Global Governance of Marine Genetic Resources, 4 Science Advances 1, 2 (2018). 
For the law to remain effective, it must respond to the growing significance of MGRs and avoid remaining incomplete. ${ }^{20}$ To address this advancement, on June 19, 2015, the United Nations General Assembly adopted a resolution to "develop an internationally legally binding instrument" ("ILBI") on UNCLOS to address biodiversity in areas beyond its national jurisdiction. ${ }^{21}$ However, a number of actors - states, industrial stakeholders, and academics - influence the speed and direction of such an evolutionary process. ${ }^{22}$ The focus of this paper is to identify the most efficient method to facilitate fair and equitable distribution and thus reduce the gap between states of the Global North and of the South.

The complex nature of this legal issue results from two regulatory gaps in science and technology. The first is within the international law of the sea, and the second is within biodiversity law.

UNCLOS splits the ocean into different maritime zones and regulates the activities that can be conducted within these areas. ${ }^{23}$ This division of the maritime zones has resulted in MGRs' ambiguous legal status in the ABNJ and a disagreement on whether the ABNJ is subject to the principle of the Common Heritage of Mankind ("CHM") or to the freedom of the high seas. ${ }^{24}$ Broadly, the CHM principle recognizes that users must not appropriate the resources; the resources must remain accessible to all, and the benefits must be shared equitably. ${ }^{25}$ Alternatively, the freedom of the high seas envisages a free market situation where property can be used for individual benefit and claimed on a "first-come-first-served" basis. ${ }^{26}$

The second is the efficiency of the ABS framework itself and the granting of patents to these inventions. Recently, the workability of the ABS framework in the light of technological advances came into question. ${ }^{27}$ Further, patents leading to exclusive rights have been identified as a hindrance to equitable distribution and scientific

20. See Wynberg, supra note 11, at 414.

21. G.A. Res. 69/292, Development of an International Legally Binding Instrument Under the United Nations Convention on the Law of the Sea on the Conservation and Sustainable Use of Marine Biological Diversity of Areas Beyond National Jurisdiction, I 1 (June 19, 2015).

22. See Beslier, supra note 3 , at 338-39.

23. See UNCLOS, supra note 10.

24. Blasiak et al., supra note 19 , at 4.

25. See generally E.D. Brown, Freedom of the High Seas Versus Common Heritage of Mankind: Fundamental Principles in Conflict, 20 SAN DiEgO L. R. 521 (1983).

26. Id.

27. Manuel Ruiz Muller, Access to Genetic Resources And Benefit-Sharing 25 Years on: Progress and Challenges 2 (2018). 
advancement. ${ }^{28}$ In addressing these two concerns, this paper aims to formulate a solution that maximizes benefits by incentivizing innovation as well as allowing these benefits to reach downstream users.

Through the lens of the development agenda, this paper seeks to answer the research question of whether patents can be designed in a way that maximizes the benefits to be distributed. Section I addresses the legal status of the MGRs found in the ABNJ. Then, Section II examines the effective working of the ABS framework so far and the patentability of genetic material. Specifically, it will identify the role of patents within this framework. Section III discusses the possible solutions proposed by academics and states at different conferences. Finally, it will be evaluated whether these solutions help reach the result of equitable distribution in the last section. It is suggested that given the political tensions and irreconcilability, the effective solution may not lie in patents and ABS, but instead in "nondominium" or trusteeship principles.

\section{Legal Status of the ABNJ And Policy BACKGROUND}

Before delving into the equitable distribution of benefits, it is important to gain a better understanding of where MGRs are found within the ABNJ, and how they are placed within the existing legal regime. This section will first define the ABNJ in legal terms. Then, having identified the existing regulatory gap, this section will address the possible solutions to resolve this issue. Finally, it will evaluate these solutions, keeping in mind the concerns of the stakeholder, to identify the appropriate legal status that would forge a path towards equitable distribution and development.

\section{A. The Regulatory Gap - Access and Benefit Sharing of MGRs beyond national jurisdiction}

A unique characteristic of MGRs found within the ABNJ is that these oceanic regions do not fall under the jurisdiction of any one state. ${ }^{29}$ Therefore, the resources found in such an area are not the property of any one state. ${ }^{30}$ As the present discussions concern genetic material found in this area, the question of their legal status is more complex. Three main legal instruments contribute to the legal regime: the UNCLOS, ${ }^{31}$ the CBD, ${ }^{32}$ and the Trade Related Intellectual Property

28. Blasiak et al., supra note 19 , at 4 .

29. Id.

30. $I d$.

31. UNCLOS, supra note 10.

32. CBD, supra note 8 . 
Rights Agreement ("TRIPS"). ${ }^{33}$ One pillar of these three instruments is the recognition of the State's sovereign rights on the genetic resources that reside within their territory. ${ }^{34}$ These rights apply to genetic resources found within national jurisdictions. ${ }^{35}$

1. The UNCLOS and MGRs Common Heritage of Mankind vs Freedom of the High Seas

The ABNJ consists of the seabed, the ocean floor and subsoil, and the high seas. ${ }^{36}$ The high seas stretch beyond the Exclusive Economic Zone, ${ }^{37}$ the territorial and internal waters of states, and extend to the geomorphological limits of the ocean. ${ }^{38}$ Although the UNCLOS mentions the mineral resources found within the ABNJ, ${ }^{39}$ it makes no mention of the genetic resources and activities such as marine bioprospecting. ${ }^{40}$ These concepts were not envisioned at the time of drafting in 1982. ${ }^{41}$ Even so, the UNCLOS remains relevant to our discussion because it is known as the constitution of the oceans and is concerned with the regulation of all activities carried out in the oceans and the seas. ${ }^{42}$

While the $A r e a^{43}$ and the water column ${ }^{44}$ are governed by two different regimes, MGRs can be found in both. ${ }^{45}$ Part XI of the UNCLOS regulates the seabed and deems it to be the common heritage

33. Marrakesh Agreement establishing the World Trade Organization, art. IV ๑ๆ 5-6, Apr. 15, 1994, 1867 U.N.T.S. 156 [hereinafter TRIPS] (establishing oversight over intellectual property).

34. CBD, supra note 8, at art. 3; Nagoya Protocol, supra note 15, at art. 6 1 .

35. Id.

36. See UNCLOS, supra note 10, at art. 1(1).

37. See id. at art. 76 .

38. Id.

39. Id. at art. 77 .

40. See generally id.

41. Hauiwen He, Limitations on Patenting Inventions Based on Marine Genetic Resources, 29 InT'L J. OF MARIne And CoAstal L. 521, 523 (2014).

42. G.A. Res. 65/37, Oceans and the Law of the Sea, at 2 (Dec. 7, 2010).

43. UNCLOS, supra note 10, at art. 1(1).

44. Charlotte Salpin \& Valentina Germani, Patenting of Research Results Related to Genetic Resources from Areas Beyond National Jurisdiction: The Crossroads of the Law of the Sea and Intellectual Property Law, 16 Rev. Eur. Cmty. \& Int'L Env'T. L. 12, 15-16 (2007).

45. He, supra note 41 , at 522 . 
of mankind. ${ }^{46}$ Specifically, Articles 136 and 137 provide that no State shall claim to have sovereign rights over these resources, and that the activities in the Area should be carried out for the benefit of all mankind $^{47}$ and regulated by the International Seabed Authority. ${ }^{48}$ However, Part VII of the UNCLOS establishes that the water column beyond national jurisdiction is open to all states and is subject to the freedom of the high seas. ${ }^{49}$ These freedoms include navigation and fishing, but they are restricted as a result of the due regard given to other states. ${ }^{50}$

Currently, marine bioprospecting is carried out under the principle of marine scientific research enshrined in Part XIII of the UNCLOS. ${ }^{51}$ This principle generally governs research within the ABNJ, but is once again restricted by the due regard given to the rights of other states. ${ }^{52}$ The UNCLOS specifically states that such scientific research shall not give rise to any legal claims to any part of the marine environment or its resources. ${ }^{53}$ Further, States are required to promote the transfer of knowledge and flow of scientific data resulting from such research. ${ }^{54}$ Additionally, scientific research in the Area is required to be conducted for the benefit of mankind as a whole. ${ }^{55}$ This stipulates that States have to act in aid of international cooperation, in scientific research, and the transfer of technology, particularly to developing states. ${ }^{56}$

This distinction leads to a fundamental problem when applying the UNCLOS to MGRs; it is uncertain which framework would apply ${ }^{57}$ because their origin is not ascertainable. ${ }^{58}$ If the research is carried out

46. UNCLOS, supra note 10, at art. 136.

47. Id. at arts. 136, 137.

48. $\quad I d$. at art. $137(2)$.

49. Id. at art. 87 .

50. Id.

51. Id. at art. 143 .

52. Id. at art. 238.

53. Id. at art. 241; Montserrat Gorina-Ysern, Marine Scientific Research Activities as the Legal Basis for Intellectual Property Claims?, 22 MARINE POL'Y 337, 342 (1998).

54. UNCLOS, supra note 10, at art. 244.

55. Id. at art. 143(1).

56. Id. at art. 144.

57. U.N. GAOR, Letter dated 15 May 2008 from the Co-Chairpersons of the Ad Hoc Open-ended Informal Working Group to study issues relating to the conservation and sustainable use of marine biological diversity beyond areas of national jurisdiction addressed to the President of the General Assembly, ๆ 36, U.N. Doc. A/63/79 (May 16, 2008) [hereinafter A/63/79].

58. Bonfanti \& Trevisanut, supra note 4, at 193. 
in the Area, it obligates the States sponsoring such activities to conduct due diligence and remain answerable to the International Seabed Authority. ${ }^{59}$ Further, they would be liable for damages if they failed to comply. ${ }^{60}$ Moreover, States would have to ensure that the research was being conducted for the benefit of all mankind and show the equitable distribution of benefits. ${ }^{61}$ On the other hand, if the research was conducted in the water column, the obligations placed on States to ensure transfer of knowledge has a significantly less rigorous standard. ${ }^{62}$ The States would be free to access the MGRs within the ABNJ to conduct marine bioprospecting and to do so without obligation to ensure public availability of information or to distribute benefits among developing States. ${ }^{63}$

\section{Political Impasse - Diverging Opinion}

There is considerable disagreement as to whether the MGRs are the common heritage of mankind or whether the freedom of the high seas must apply. ${ }^{64}$ Although this regulatory gap has been identified previously ${ }^{65}$ and countries have put forth their diverging opinions, arguably stemming from their vested interests, no consensus on which regime must apply has yet been reached. ${ }^{66}$ For instance, at the 2007 UN Informal Consultative Process on Oceans and the Law of the Sea, several States reiterated their view that "all the resources of the Area, including marine genetic resources were the "common heritage of

59. See generally U.N. Secretary-General, Advisory Opinion of the Seabed Disputes Chamber on the Responsibilities and Obligations of States Sponsoring Persons and Entities with Respect to Activities in the Area, U.N. Doc ISBA/17/C/6 (Mar. 4, 2011) (requesting an advisory opinion from the Seabed Disputes Chamber to the International Seabed Authority on matters relating to the responsibilities and obligations of sponsoring States).

60. UNCLOS, supra note 10, at art. 139(2).

61. Compare id. at 139(2), with id. at arts. 140, 144.

62. See id. at art. $87(2)$.

63. CEnTRE FOR International LAW, NATional University OF Singapore, REPORT OF THE BBNJ Workshop ON The Conservation and Sustainable Use of Marine Biological Diversity of Areas beyond National Jurisdiction: Preparing For the PrepCom 6 (2016) [hereinafter Centre for International LAW].

64. See generally id.

65. U.N. Secretary General, Oceans and the Law of the Sea, 9227 , U.N. Doc. A/60/63/Add.1 (July 15, 2005).

66. See id. ๆ 178 . 
mankind.'" ${ }^{67}$ Other delegations put forth a different view that these resources fell outside the ambit of the UNCLOS and only customary international law can apply. ${ }^{68}$

Similar issues were raised at the Ad Hoc Open-ended Informal Working Group to study issues relating to the conservation and the sustainable use of marine biological diversity beyond areas of national jurisdiction ${ }^{69}$ through the Preparatory Committee. ${ }^{70}$ Presently, the Inter-governmental Conference is negotiating the new legally binding instrument to apply to this regime. ${ }^{71}$ However, even the most recent discussion regarding this issue, the Second Session of the BBNJ Conference, did not seem to make any progress towards reaching a consensus. $^{72}$

\section{The Legal Status}

As a result of the political impasse and the significance of the issue at hand, there has been a high level of academic engagement with this question. ${ }^{73}$ As this question is not the focus of this article, I only briefly touch on the arguments put forth by academics regarding which interpretation supports the development agenda.

\section{a. The Positive Approach - "As it is"}

The legal implication of the exclusion of genetic materials is debateable. Genetic resources were omitted from the initial discussions at the UNCLOS because it was then assumed that with the absence of sunlight on the ocean floor, living organisms did not inhabit it. ${ }^{74}$

67. U.N. General Assembly, Report on the Work of the U.N. Open-Ended Informal Consultative Process on Oceans and the Law of the Sea at its Eighth meeting, U.N. Doc. A/62/169, ๆ 71 (July 30, 2007).

68. Id. ๆ 74 .

69. G.A. Res. 59/24, ๆ 73 (Nov. 17, 2005); U.N. General Assembly, Letter dated Mar. 16, 2010 from the Co-Chairpersons of the Ad Hoc Open-Ended Informal Working Group to the President of the General Assembly, \ฯ 71-72, U.N. Doc. A/65/68 (Mar. 17, 2010).

70. G.A. Res. 69/292, ๆ 1 (June 19, 2015).

71. See G.A. Dec. 74/543, U.N. Doc. A/74/L.41 (Mar. 9, 2020).

72. Intergovernmental Conference on an International Legally Binding Instrument Under the United Nations Convention on the Law of the Sea on the Conservation and Sustainable Use of Marine Biological Diversity of Areas Beyond National Jurisdiction, Statement by the President of the Conference at the Closing of the Third Session, at 3, U.N. Doc. A/CONF.232/2019/10 (Sept. 13, 2019) [hereinafter BBNJ Conference].

73. See, e.g., Beslier, supra note 3; Blasiak et al., supra note 19.

74. Centre for International LAw, supra note 63 , at 8. 
However, today we know that a wide variety of organisms live near or at the seafloor of the Area..$^{75}$

Application of the Vienna Convention on the Law of the Treaties ("VCLT") 76 rule of general interpretation seems imperative to interpret the treaty provisions and will serve as the point of departure for this analysis. As the VCLT has repeatedly been referred to as customary international law by the International Court of Justice ${ }^{77}$ and the International Tribunal on the Law of the Sea ${ }^{78}$ its applicability here cannot be denied.

Adopting a positive approach, Marciniak analyzed the legal implication of this omission by applying literal, teleological, and contextual interpretations. ${ }^{79}$ If a literal interpretation is applied, it could be argued that the UNCLOS does not extend to MGRs. ${ }^{80}$ However, when a more functional approach is taken, it is required that the treaty be interpreted while keeping in mind its object or purpose ${ }^{81}$ usually set out in its preamble. ${ }^{82}$ Although the preamble of the UNCLOS acknowledges that "matters not regulated by this Convention continue to be governed by the rules and principles of general international law," it emphasizes the need for equitable and efficient utilization of the ocean's resources. ${ }^{83}$ Bearing in mind that the goals of the convention "contribute to realising a 'just' and 'equitable' international economic order," ${ }^{84}$ it can be argued that the achievement of this goal should be of paramount importance. Although this may not automatically call for the application of the CHM to the whole regime, ${ }^{85}$

75. $\quad I d$.

76. Vienna Convention on the Law of Treaties, May 23, 1969, 1155 U.N.T.S. 331 [hereinafter VCLT].

77. Pulp Mills on the River Uruguay (Arg. v. Uru.), Judgment, 2010 I.C.J. 14 ๆ 65 (Apr. 20).

78. Responsibilities and Obligations of States with Respect to Activities in the Area (Request for Advisory Opinion Submitted to the Seabed Disputes Chamber), Advisory Opinion of Feb. 1, 2011, ITLOS Rep. 2011, 10 ฯ 57.

79. Konrad Jan Marciniak, Marine Genetic Resources: Do They Form Part of the Common Heritage of Mankind Principle?, in NATURAL RESOURCES AND THE LAW ON THE SEA: Exploration, Allocation, Exploitation or Natural Resources in Areas Under National JURISDICTION AND BEYOND, 373, 384-385 (2017).

80. U.N. GAOR, 62nd Sess., 4 mtg. ๆ 74, U.N. Doc. A/62/169 (July 30, 2007).

81. Richard Gardiner, Treaty Interpretation 209-11 (2nd ed. 2015).

82. VCLT, supra note 76, at art. 31(2).

83. UNCLOS, supra note 10, pmbl.

84. Id.

85. Marciniak, supra note 79 , at 387 . 
it points to the fact that at least a few principles of the CHM should apply.

A functional analysis of the VCLT's Article 31(3) calls for an indepth interpretation of the travaux preparatoires and subsequent developments. However, this interpretation is subjective. Marciniak concludes that there was no basis to argue that the MGRs were ever included within the CHM principle. ${ }^{86}$ However, given the subjectivity of such an interpretation, others seem to disagree. In Correa's opinion, the UNGA Resolution 25/2749, which declared that the Area and its resources were the common heritage of mankind and laid the basis for Part XI of the UNCLOS, was not limited to minerals. ${ }^{87}$

From this brief analysis it appears that the application of Article 31 of the VCLT may not lend itself to the argument that MGRs are effectively covered under Part XI of the UNCLOS in a strict legal sense. However, nothing would stop the conclusion of a supporting agreement that derived principles from the objectives of the UNCLOS.

\section{b. The Normative Approach - 'As it should be'}

While the new treaty is still being negotiated and the draft text is yet to be prepared, ${ }^{88} \mathrm{I}$ argue that it is imperative to look at this question through the lens of "what ought to be." Given the significance of this debate to the scientific advancement and the development agenda, this article will aim to achieve these objectives through the arguments raised and solutions proposed.

The UNCLOS cannot be applied in isolation from other treaties and instruments of international law. ${ }^{89}$ Keeping this in mind, those applying Article 31 of the VCLT should keep in mind the wider objectives of the general body of international law.

Furthering these objectives, an International Institute for Environment and Development ("IIED") study ${ }^{90}$ argued that if we were

86. Id. at 401 .

87. Carols M. Correa, Access to and Benefit Sharing of Marine Genetic Resources Beyond National Jurisdiction: Developing a New Legally Binding Instrument, 79 South Centre 1, 9 (Sept. 2017).

88. See generally G.A. Dec. 74/543, supra note 71 .

89. See James Harrison, Reflections on the Role of International Courts and Tribunals in the Settlement of Environmental Disputes and the Development of International Environmental Law, 25 J. ENV'T L. 501, 506 (2013) (explaining a matter where an adjudicatory body held treaty rules were not to be held in isolation from the rest of the body of public international law).

90. Eleftheria Asimakopoulou \& Essam Yassin Mohammad, Marine Genetic Resources in Areas Beyond National Jurisdiction: A 'Common Heritage of Mankind,' IIED BRIEFInG (2019). 
to shift the lens of our analysis to the wider body of international law, ${ }^{91}$ it can be seen that the international courts do not view the oceans in a similar manner. ${ }^{92}$

For example, in South China Sea Arbitration, the Permanent Court of Arbitration was called upon to decide the Philippines' challenge to maritime claims made by China. ${ }^{93}$ The Court recognized that the countries had a duty to preserve marine environment both within the national jurisdiction and without. ${ }^{94}$ This demonstrates that the division of the maritime zones as the high seas or the Area, and regulating them through the use of different legal regimes, is artificial. ${ }^{95}$ The courts do not adhere to these artificial zones in their interpretations, and as a result, these divisions are obsolete. ${ }^{96}$ These artificial divisions should not act to the detriment of the wider agenda of development and scientific advancement. This interpretation affirmed that other provisions within the treaty as well as the general corpus of international law could inform the core framework of the UNCLOS. ${ }^{97}$

Further, the term "environment" under the UNCLOS was interpreted in light of the CBD definition of "ecosystem" as a "dynamic complex of plant, animal and micro-organism communities and their non-living environment interacting as a functional unit." 98 In doing so, the Court incorporated the "ecosystem approach" into Part XII of the UNCLOS concerning the marine environment. ${ }^{99}$ As a result, living and non-living organisms in ABNJ are interconnected with their habitat, and form an indivisible ecosystem. ${ }^{100}$

To apply this approach in practice requires uniform regulation of marine resources. As discussed, the CHM principle already applies to "any solid, liquid or gaseous mineral resources in situ in the Area,

91. Id. at $2-3$.

92. $I d$.

93. South China Sea Arbitration (Phil. v. China), Award, Case No. 2013-19, ฯ 2 (Perm. Ct. Arb. 2016).

94. Id. at $₫$ \ 940-941.

95. Asimakopoulou \& Mohammad, supra note 90, at 2.

96. Id.

97. Michael Sheng-ti Gau, The Interpretation of Article 121(3) of UNCLOS by the Tribunal for the South China Sea Arbitration: A Critique, 50 OCEAN DEV. \& INT'L L. 49, 56 (2019).

98. CBD, supra note 8, at art. 2 .

99. Duncan E.J. Cyrrie \& Mischa Davis, Governance Principles Relevant to Marine Biodiversity in Areas Beyond National JuRisdiction Submission to the Chair (2016), https://www.un.org/depts/los/biodiversity/prepcom_files/greenpeace.p df [https://perma.cc/9Z2U-R97G].

100. CBD, supra note 8 , at art. 2 . 
including polymetallic nodules." ${ }^{101}$ Therefore, to achieve uniformity in the regulation of marine resources, the CHM must also apply to MGRs.

Therefore, if we were to look at the issue of the legal status of MGRs within the ABNJ through this wider lens, it is possible to extend the interpretation of Part XI of the UNCLOS to MGRs. The case for basing the new instrument on the CHM principle can be made stronger if the interests of science and development are considered.

\section{In the Interest of Science and Development}

Further, the principle that certain areas are to be used for the benefit of all exists as a general principle of law even outside the scope of the UNCLOS. ${ }^{102}$ If a normative approach applied to Article 31(3)(c) of the VCLT, the general principles of international law, including this principle, could be included in this interpretation.

The preamble of the World Heritage Convention ("WHC") highlights that,

the importance, for all the peoples of the world, of safeguarding this unique and irreplaceable [cultural and natural] property, to whatever people it may belong . . . considering that parts of the cultural or natural heritage are of outstanding interest and therefore need to be preserved as part of the world heritage of mankind as a whole. ${ }^{103}$

Given that the exceptional habitats, sensitive and endangered species of the ABNJ are of outstanding universal value ("OUV") as recognized under the WHC, ${ }^{104}$ it is likely to be regarded as world heritage. If the marine sites of the ABNJ are recognized as world heritage, then that further necessitates the theory that the benefits accruing from their exploitation or exploration should be shared by humanity as a whole. ${ }^{105}$

This principle is also recognized by the ICJ. In his separate opinion, Judge Weeramantry acknowledged that the earth's resources are "not individually, but collectively owned." 106 The principle of intra and intergenerational equity was acknowledged in the well-known Nuclear

101. UNCLOS, supra note 10, at art. 133.

102. Lawrence A. Kogan, What Goes around Comes around: How UNCLOS Ratification Will Herald Europe's Precautionary Principle as U.S. Law, 7 Santa Clara J. Int'L L. 23, 70 (2009).

103. Convention Concerning the Protection of the World Cultural and Natural Heritage, Nov. 16, 1972, 1037 U.N.T.S. 151.

104. Id.

105. Asimakopoulou \& Mohammad, supra note 90, at 3.

106. Gabčíkovo-Nagymaros Project (Hung. v Slovak.), Judgment, 1997 I.C.J. Rep. 7, 107 (Sept. 25) (separate opinion by Weeramantry, J.). 
Weapons Advisory Opinion. ${ }^{107}$ In recognizing that the environment "represents the very health of human beings, including generations unborn," 108 the Court upheld the right of present and future generations to not only live in a healthy environment, but to also have its natural elements fairly and equitably shared. ${ }^{109}$

The right to share in scientific advancement and its benefits is recognized in Article 27 of the Universal Declaration of Human Rights ("UDHR"). ${ }^{110}$ Although the UDHR is not a legally binding instrument, ${ }^{111}$ academics have acknowledged that the provisions could evolve to form binding norms as customary international law. ${ }^{112}$ Even though the academics arguing that the UDHR is customary international law in toto are in the minority, ${ }^{113}$ it is still worth arguing because scientific advancement is indispensable to development. ${ }^{114}$

In an indivisible ecosystem such as the ABNJ, ${ }^{115}$ applying the equitable distribution principles enshrined in the preamble of the UNCLOS can only be effectively realized through the applying the CHM principle. Moreover, developing countries likely could be excluded from both access and benefit-sharing of scientific research into MGRs without uniform regulation of scientific exploration regarding MGRs in ABNJ. That, by itself, would constitute a violation of the "human right to science" which includes the right to share in scientific advancement and its benefits. ${ }^{116}$

While the UNCLOS omitted to include MGRs within its core framework, ${ }^{117}$ a new internationally binding instrument is being negotiated. ${ }^{118}$ However, even though this regulatory gap has been identified for some time now, it is still unclear which legal regime would

107. Legality of the Threat or Use of Nuclear Weapons, Advisory Opinion, 1996 I.C.J. Rep. 226, ๆ 29 (July 8).

108. Id.

109. Id.

110. G.A. Res. 217 (III) A, Universal Declaration of Human Rights, art. 27 (Dec. 10, 1948).

111. Richard Pierre Claude \& Bernardo W. Issel, Health, Medicine and Science in the Universal Declaration of Human Rights, 3 Health \& Hum. RTs. 126,139 .

112. See, e.g., Kogan, supra note 102.

113. Hurst Huannum, The UDHR in National and International Law, 3 HeAlth \& Hum. RTs.144, 148 (1998).

114. See, e.g., Kogan, supra note 102.

115. Asimakopoulou \& Mohammad, supra note 90 , at 3 .

116. See, G.A. Res. 217 (III) A, supra note 110, art. 27.

117. Asimakopoulou \& Mohammad, supra note 90 , at 1.

118. Id. 
apply. ${ }^{119}$ By briefly engaging with the implications of the application of the legal regimes on the development agenda, it is concluded that the application of CHM to the MGRs within the ABNJ would help achieve the most equitable solution.

Acknowledging the lack of political consensus, ${ }^{120}$ this section aims to take the discussions further by briefly interpreting the treaty's provisions. In doing so, I kept in mind the overarching objective of this article: to arrive at a solution that is in the best interest of scientific advancement and development.

If the VCLT was applied in a narrow sense and with a positive approach, the freedom of the high seas would apply to the MGRs within the ABNJ. However, these interpretations are subjective and academic opinions differed when employing similar interpretations. ${ }^{121}$ Given the lack of academic consensus, this article adopts a normative approach to this legal analysis. By identifying the developments in other areas of international law and applying them to the issue at hand, this section identified that arguments for applying the CHM principle to the new instrument could be made through the viewpoints regarding the right to the science, inter and intra-generational equity, and world heritage.

Therefore, although the lack of political consensus on the legal status of MGRs within the ABNJ poses a problem to the development agenda, ${ }^{122}$ the problem can be avoided by applying a normative approach to the legal analysis. Even though the question of the management of resources could also be discussed without any agreement on the legal status, this might result in the formulation of "a dependent and normatively incoherent governance regime." 123 The analysis of the most equitable solution will progress under the assumption that the CHM principle applies.

119. See, Kogan, supra note 102, at 46.

120. Sivaramjani Thambisetty, Marine Genetic Resources Beyond National Jurisdictions: Components of a Fair, Informed and Progressive Internationally Binding Legal Instrument, SSRN https://papers.ssrn.com/sol3/papers.cfm?abstract_id=3215356

(2018) [https://perma.cc/WC9T-9F4M].

121. See Chuxiao Yu, Implications of the UNCLOS Marine Scientific Research Regime for the Current Negotiations on Access and Benefit Sharing of Marine Genetic Resources in Areas Beyond National Jurisdiction, 51 OCEAN DEV. \& INT'L L. 2, 5 (2019).

122. Thambisetty, Marine Genetic Resources Beyond National Jurisdictions, supra note 120.

123. Id. 


\section{The Role of Patents Within the Access And BENEFIT-SHARING FRAMEWORK}

Building on the legal analysis above, this section seeks to address the second regulatory gap found in the biodiversity law, namely the access and benefit-sharing ("ABS") of genetic resources originating beyond national jurisdiction. A central aim of this chapter is to analyze the role of patents within the ABS framework and how they can be designed more effectively and efficiently. First, this chapter will outline this regulatory gap within the CBD and the Nagoya Protocol, and identify the role of patents within the ABS framework. Then, the article outlines the requirements of patent protection for MGRs. Having placed the role and the nature of patent protection within the ABS, the chapter then identifies how each of these could hinder the delivery of benefits to all.

\section{A. The Regulatory Gap - Genetic Resources Beyond National Jurisdiction}

Much like the gap within the UNCLOS, the scientific inventions derived from MGRs within the ABNJ go unregulated in biodiversity law. ${ }^{124}$ This section will deal with the legal issues surrounding the CBD and TRIPS regarding the equitable distribution of these resources.

\section{Biodiversity Law and MGRs}

In 1992, the adoption of the CBD established a broad framework for member states to implement national laws directed at the conservation of biodiversity, the sustainable use of the components, and the fair and equitable sharing of benefits arising from the use of genetic resources. ${ }^{125}$ With 196 contracting parties, ${ }^{126}$ the CBD has become the main framework used by the international community to protect against the loss of biodiversity. ${ }^{127}$ Sovereignty, prior informed consent ("PIC") and mutually agreed terms ("MAT") have become the tools to ensure the benefit-sharing. ${ }^{128}$

124. Blasiak et al., supra note 19 , at 1 .

125. CBD, supra note 8 , at art. 1 .

126. List of Parties, Convention on Biological Diversity, https://www.cbd.int/information/parties.shtml [https://perma.cc/VW9W-DS6U].

127. See, e.g., Convention on Biological Diversity, Ocean Health Index, http://www.oceanhealthindex.org/methodology/components/convention -on-biological-diversity [https://perma.cc/47SE-LRLR].

128. MUlLER, supra note 27 , at 4. 
The Nagoya Protocol was adopted to clarify and strengthen the benefit-sharing laid down in the CBD. ${ }^{129}$ It aimed to do so by facilitating the sharing of benefits in a fair and equitable manner by establishing a transnational Access and Benefit-Sharing Clearing House ("ABS Clearing House"). ${ }^{130}$ Both the CBD and the Nagoya Protocol recognize "mutually agreed terms" that provide that specific access and benefit-sharing conditions must be agreed upon by users and providers of genetic resources. ${ }^{131}$ The Nagoya Protocol also establishes the issuance of internationally recognized certificates by the relevant national authority, which certify that a genetic resource has been obtained, accessed, and used per prior consent of the national authority having jurisdiction over the genetic resource. ${ }^{132}$ Where PIC is not possible, Article 10 of the Nagoya Protocol calls for the establishment of the "global multi-lateral benefit sharing mechanism." 133 It states,

Parties shall consider the need for and modalities of a global multilateral benefit-sharing mechanism to address the fair and equitable sharing of benefits derived from the utilization of genetic resources and traditional knowledge associated with genetic resources that occur in transboundary situations or for which it is not possible to grant or obtain prior informed consent. ${ }^{134}$

The words "it is not possible to grant or obtain prior informed consent" 135 have been said to imply that the global multilateral mechanism includes MGRs within ABNJ. ${ }^{136}$ Although this provision appears to fill the gap identified in the UNCLOS above, the Preamble of the Nagoya Protocol reaffirms that it applies to "the sovereign rights of States over their natural resources and according to the provisions of the Convention." "137 Therefore, it would be difficult to interpret the

129. See About the Nagoya Protocol, Convention on Biological DIVERSITY, https://www.cbd.int/convention/ [https://perma.cc/X2C2$\mathrm{X} 8 \mathrm{DW}]$.

130. Nagoya Protocol, supra note 15, at art. 1; CBD, supra note 8, at art. $18(3)$.

131. Nagoya Protocol, supra note 15, at art. 18; CBD, supra note 8, at art. 15.

132. Nagoya Protocol, supra note 15, at art. 17.

133. Id. at art. 10 .

134. Id.

135. Id.

136. See, e.g., Su Jin Park, Changes in the Law of Marine Genetic Resources in the ABNJ and under the UNCLOS, in OCEAN LAW DeBates: The 50-Year Legacy and Emerging Issues 419, 420 (Harry N. Scheiber et al. eds., 2018).

137. Nagoya Protocol, supra note 15, pmbl. 
Nagoya Protocol as applying outside the boundaries of the CBD, whose jurisdictional scope only stretches within national jurisdictions. ${ }^{138}$ The $\mathrm{CBD}$ and the Nagoya Protocol apply to areas beyond national jurisdiction in so much as the States are regulating the activities of their own nationals. ${ }^{139}$

In areas beyond national jurisdiction, Article 5 of the CBD provides that States must cooperate directly with each other or through competent international organizations for the conservation and sustainable use of biological diversity. ${ }^{140}$ The geographical coverage of the CBD and the Nagoya Protocol once again leave the regulatory gap of access and benefit-sharing agreements for MGRs within ABNJ.

\section{Intellectual Property Rights, ABS frameworks and MGRs}

As MGRs originating from ABNJ are used to invent life-saving pharmaceuticals and biofuels, ${ }^{141}$ it is increasingly important to promote bioprospecting and innovation. Intellectual property protection, specifically patents, may help promote both. Patents provide timed exclusive rights to the creator in exchange for disclosure of information required to replicate the invention. ${ }^{142}$

The CBD explicitly recognizes that IPRs may have an impact on the implementation of its objectives to the extent that they involve the assertion of private rights of ownership over biodiversity-generated innovations. ${ }^{143}$ In particular, intellectual property clauses may influence mutually agreed upon terms with regard to the utilization of genetic resources. ${ }^{144}$ But given the lack of clarity on the ABS framework

138. CBD, supra note 8, at art. 4; see generally BeVIS FEdDER, MARINE Genetic Resources, Access and Benefit Sharing: Legal and Biological Perspectives (2013).

139. See generally Frédéric Jacquemont \& Alejandro Caparrós, The Convenion on Biological Diversity and Climate Change Convention 10 Years After Rio: Towards a Synergy of the Two Regimes?, 11 RECIEL 169 (2002).

140. CBD, supra note 8, at art. 5 .

141. See, e.g., Marjo Vierros et al., Who Owns the Ocean? Policy Issues Surrounding Marine Genetic Resources, 25 Limnology \& OCEANOGRAPHy Bull. 29, 29-35 (2016).

142. See Patents, World Intellectual Property Org., https://www.wipo.int/patents/en/ [https://perma.cc/8WYS-SH8A].

143. CBD, supra note 8, at art. 1; Nagoya Protocol, supra note 15, at arts. 1, 15 .

144. World Intell. Prop. Org., A Guide to Intellectual Property Issues in Access And Benefit-Sharing Agreements 10 (2018). 
applicable to MGRs within ABNJ, ${ }^{145}$ the intellectual property protection for these resources remains unregulated.

However, before considering the overall impact of patents within the ABS framework, it is imperative to discuss the requirements for the patentability of inventions derived from MGRs.

\section{Patentability of MGR-based inventions and processes}

A patent is an "exclusive right granted for an invention, which is a product or a process that offers a new technical solution to a problem or provides a new way of doing something." ${ }^{46}$ At the outset, it seems the exclusive rights granted under patents principally clash with the CHM principle. However, after much academic debate, there is a broad consensus that no conceptual conflict exists between the UNCLOS provisions on marine scientific research and the objectives of intellectual property protection. ${ }^{147}$ They are both founded on the belief that universality of scientific knowledge is a foundation for the advancement of mankind. ${ }^{148}$

Once a patent is secured, it gives the patent owner the exclusive right to prevent others from commercially exploiting the patented invention for the period in which the invention is protected. ${ }^{149}$ Patent rights are subject to territoriality, thus a patent needs to be sought distinctly in each country or region. ${ }^{150}$ For example, the European Patent Convention ("EPC") only applies to the patents registered within the territory of each contracting State. ${ }^{151}$ Although granted by sovereign States, the basic pre-requisites to obtain a patent have

145. Glen Wright et al., The Long and Winding Road: Negotiating a Treaty for the Conservation and Sustainable Use of Marine Biodiversity in Areas Beyond National Jurisdiction 34 (2016), https://www.actu-environnement.com/media/pdf/news-31928-iddrihaute-mer.pdf [https://perma.cc/EM77-LVTX].

146. Patents, supra note 142 .

147. See Eve Heafey, Access and Benefit Sharing of Marine Genetic Resources from Areas beyond National Jurisdiction: Intellectual Property - Friend, Not Foe, 14 CHI. J. InT'L L. 493, 498 (2014); He, supra note 41, 527-30; Salpin \& Germani, supra note 44.

148. See, e.g., Dana Dalrymple, Scientific Knowledge as a Global Public Good: Contributions to Innovation and the Economy, in THE ROLE OF Scientific and Technical Data and Information in the Public Domain: Proceedings of a Symposium 35, 36 (2003); UNCLOS, supra note 10, pmbl.

149. See Patents, supra note 142.

150. World Intell. Prop. Org., supra note 144, at 28.

151. European Patent Convention art. 52, Oct. 5, 1973, 1065 U.N.T.S. 199. 
reached harmonization. ${ }^{152}$ This is largely a result of international trade. The main requirements can be identified as being: novelty, inventive step, and industrial utility. ${ }^{153}$

\section{a. Novelty, Inventive Step and Industrial Application}

TRIPS requires patents be available for inventions in "all fields of technology, provided that they are new, involve an inventive step and are capable of industrial application." 154 These requirements need to be fulfilled for a grant of a patent application. ${ }^{155}$ First, novelty refers to an invention possessing a novel characteristic that is not present in the existing body of knowledge, termed as "prior art." 156 With regard to MGRs found in the ABNJ, this requirement should be relatively easy to satisfy because marine bioprospecting for these resources is still at the nascent stages. ${ }^{157}$ However, for genetic material, the second requirement of an inventive step may be the deciding factor. Intellectual property refers to creations of the mind, like inventions, literary and artistic works, as well as designs, symbols, names and images used for commercial purposes. ${ }^{158}$ The invention must have an inventive or nonobvious step that an ordinary person with reasonable skill could not have come up with. ${ }^{159}$ Mere discovery of a living organism that occurs in nature is not eligible for patent protection. ${ }^{160}$ Therefore, marine life

152. See, e.g., Suma Athreye, Lucia Piscitello, \& Kenneth C. Shadlen, TwentyFive Years since TRIPS: Patent Policy and International Business, $13 \mathrm{~J}$. INT'L Bus. POL'Y. 315, 316 (2020).

153. Conditions for a Patent, Swedish Intell. Prop. Office, https://www.prv.se/en/patents/applying-for-a-patent/before-theapplication/conditions-for-a-patent/ [https://perma.cc/EZX6-MUUT].

154. TRIPS, supra note 33, art. 27.

155. See id.

156. Jeffrey M. Kaden, Patent Protection and the Novelty Requirement, Gottlieb, Rackman, \& Reisman, P.C.,

https://grr.com/publications/patent-protection-novelty-requirement/ [https://perma.cc/M36A-KQSQ].

157. See, e.g., Glen Wright et Al., The Long and Winding Road Continues: Towards a New Agreement on High Seas

GOVERNANCE 14,

https://www.iddri.org/sites/default/files/import/publications/st0116_g w-et-al._high-seas.pdf [https://perma.cc/U4CP-JYLH].

158. What is Intellectual Property? World Intell. Prop. OrG., http://www.wipo. int/about-ip/en/ [https://perma.cc/S383-WZYY].

159. TRIPS, supra note 33, art. 27.

160. See Jake Mace, Can a Living Organism be Patented? The Quick Answer is "Sometimes", IP WIRE (July 31, 2017), http://ipwire.com/stories/patentability-living-organisms/

[https://perma.cc/N4L8-9DP5]. 
forms and access to MGRs may not themselves be patented. ${ }^{161}$ Regarding derivatives of these organisms or genetically modified organisms, national laws differ. ${ }^{162}$ Essentially, they need to be subject to human intervention but the degree of intervention varies between jurisdictions. ${ }^{163}$

In the European Union ("EU"), inventions stemming from genetic material could be considered patentable inventions if they are isolated from their natural environments or produced by a technological process. ${ }^{164}$ In the United States ("US"), patenting genetic material is more stringent following the Supreme Court's ruling in Association of Molecular Pathology v. Myriad Genetics Inc. ${ }^{165}$ which stated that merely isolating DNA was not enough to fulfil the novelty requirement. ${ }^{166}$ However, this added hurdle is not insurmountable. It is quite simple for businesses to derive DNA from the genetic material which remains patentable. ${ }^{167}$

On the other hand, in the case of genetic material there may be ethical implications to consider. Patent applications under the World Trade Organization ("WTO") are subject to cultural and moral considerations, termed ordre public. ${ }^{168}$ So, although derivations of genetic material are patentable, applications will only be granted if the derivatives do not offend public morality. ${ }^{169}$

To comply with the first two requirements of "novelty" and "inventive step," it is important not to disclose technical information

161. Kristen E. Zewers, Bright Future for Marine Genetic Resources, Bleak Future for Settlement of Ownership Rights: Reflections on the United Nations Law of the Sea Consultative Process on Marine Genetic Resources, 5 Loy. InT'L L. REV. 151, 159 (2008).

162. See e.g., Alice Yuen-Ting Wong \& Albert Wai-Kit Chan, Genetically modified foods in China and the United States: A primer of regulation and intellectual property protection, 5 FOOD SCI. \& HUM. WellnESS 124 (2016); Andrew W. Torrance, Intellectual Property as the Third Dimension of GMO Regulation, 16 KAN. J. L. \& PUB. POL'Y 257 (2007).

163. See generally Jan Holthuis \& Marc van der Velden et al., Plant variety rights versus plant patents: legal developments and frictions in a regional perspective, 20 Bus. L. INT'L 96 (2019).

164. Council Directive 98/44, arts. 20 \& 21, 1998 O.J. (L.213) 13.

165. Assn. for Molecular Pathology v. Myriad Genetics Inc. 569 U.S. 576 (2013).

166. Id. at 18 .

167. See Sivaramjani Thambisetty, Alice and Something More: The Drift Towards European Patent Jurisprudence, 3 J. L. Bioscience 693 (2016).

168. Council Directive 98/44, art. 36, 1998 O.J. (L.213) 13.

169. Id. at art. 37. 
about the invention before submitting the patent application. ${ }^{170}$ However, the technical information about the invention must be disclosed to the public in a patent application, which then becomes a valuable source of information for inventors, enterprises, and researchers. ${ }^{171}$ This early disclosure of information may prejudice a later patent application, particularly regarding MGRs - which will be discussed in a later section of this Chapter.

Finally, the invention must also be capable of industrial application and do more than further a theoretical purpose. ${ }^{172}$ This requirement may pose a significant hurdle to patents for MGR-based inventions. As the end-to-end process of bioprospecting for genetic material can take years with very few MGRs progressing to the clinical trial stage, ${ }^{173}$ industrial application can only be achieved at the end. Therefore, there is not an adequate incentive to conduct marine scientific research through the current patent regime.

\section{b. The impact of patents on the ABS Framework}

Now that this paper discussed the prerequisites for the patentability of MGRs within the ABNJ, it is essential to analyze the impact of patents on the efficiency of the ABS framework to effectively answer the research question. As mentioned earlier, while the granting of patents has an impact on the implementation of the CBD's objective of equitable distribution, ${ }^{174}$ it remains unclear what the impact would be.

Many States have expressed their concerns regarding intellectual property claims over inventions derived from MGRs within ABNJ. ${ }^{175}$ These States generally fear that granting IPRs to these discoveries may result in less knowledge available to the public. ${ }^{176}$ On the other hand, some States insist that restricting the intellectual property regime regarding MGRs will decrease incentives for investments, thereby stifling research and development in this field and depriving the public

170. World Intell. Prop. Org., supra note 144, at 28.

171. Id. at 28 .

172. Id.

173. See id. at 59 .

174. See Catherine Monagle, Biodiversity $\&$ Intellectual Property Rights: Reviewing Intellectual Property Rights in Light of the Objectives of the Convention on Biological Diversity, WWF (Mar. 2011), https://www.ciel.org/Publications/tripsmay01.PDF [https://perma.cc/N2HV-VPDM].

175. See Co-Chairpersons of the Ad Hoc Open-ended Informal Working Group, Letter Dated Mar. 16, 2010 from the Co-Chairpersons of the Ad Hoc Open-Ended Informal Working Group to the President of the General Assembly, U.N. Doc. A/65/68 (Mar. 17, 2010), [hereinafter "A/65/68"].

176. See id. at 73 . 
of valuable advancements. ${ }^{177}$ In essence, to arrive at the best possible solution, the regime should provide incentives to continue discovering the mysteries of the ABNJ while ensuring a fair and equitable sharing of benefits of the research. ${ }^{178}$

Article 16(5) of the CBD requires member States to cooperate in this regard subject to national legislations and international law; this ensures that such rights are supportive and do not run counter to its objectives. ${ }^{179}$ Therefore, it is essential that the concerns regarding intellectual property claims over inventions derived from MGRs within ABNJ are addressed at the BBNJ.

Further, in recent years, the ABS framework and its core premise of sharing the benefits that arise from utilization have come into question. ${ }^{180}$ Keeping this in mind, and the concerns raised by the States, this article considers whether patents will hinder or help the delivery of benefits to all.

4. Effectively using Patents to Improve the Efficiency of the ABS Framework

Within international law, benefit-sharing is used to imply an international obligation, a treaty objective, a right, a mechanism or a safeguard. ${ }^{181}$ There is no single definition of the concept and it is yet to be fully developed or become satisfactorily operational. ${ }^{182}$ However, even to the extent that it has been put into practice, it has not been the success that it was touted to be and rarely reaches its objectives. ${ }^{183}$

With reference to developing technology in the research and development process of genetic resources, Muller identified shortcomings within the ABS framework. ${ }^{184}$ Muller's 2018 study identifies that limitations of the ABS framework persist and almost no

177. See e.g., Salpin \& Germani, supra note 44, at 23.

178. See id.

179. CBD, supra note 8 , at art. $16(5)$

180. MulLER, supra note 27.

181. Elisa Morgera, An International Legal Concept of Fair and Equitable Benefit-Sharing, 2 (Univ. Edinburgh School of L. Rsch., Working Paper No. 6, 2015).

182. See D. Schroeder, Benefit Sharing: It's Time for a Definition, 33 J. MED. ETHICS 205, 205 (2007).

183. See e.g., Sarah Laird \& Rachel Wynberg, Access and Benefit SHARING: KeY POINTS FOR POLICY-MAKERS - INDUSTRIAL Biotechnology, ABS Capacity Dev. Initiative (Nov. 2015), http://www.absinitiative.info/fileadmin/media/Knowledge_Center/Pulications/Sectoral _Briefs/Sectoral_Brief____Botanicals-_2015.pdf [https://perma.cc/J5L4-W7EQ].

184. MULLER, supra note 27, at 1-2. 
monetary benefits are shared among users and providers. ${ }^{185}$ To remain effective, the ABS framework must accommodate the realities of research and development and catch up with technological advances. ${ }^{186}$ Muller's study conducts a qualitative assessment on ABS by examining the shifting interests of stakeholders. ${ }^{187}$ It highlights a noticeable imbalance between high investments in ABS and the relatively low returns and results. ${ }^{188}$ It unearthed the underlying inefficiency issues in an ABS regime that relies on contracts to capture fair and equitable benefits. ${ }^{189}$ The empirical study also identified that in the last two decades, the investment in ABS has reduced and the monetary benefits derived from it have "flatlined." 190 Thus, the only true indicators of economic value are gleaned from products that reach the market. ${ }^{191}$

Further, the difficultly in quantifying non-monetary benefits has rendered benefit-sharing a mere tick-boxing exercise, where the users merely must claim these benefits have been shared. ${ }^{192}$ Non-monetary benefits can be in the form of jobs created, technical assistance, etc. ${ }^{193}$ They are generated as part of more traditional research cooperation between countries and institutions. ${ }^{194}$

In summary, both a lack of monetary benefits and the difficulty in tracing the non-monetary benefits explain to the inefficiency of the ABS Framework. Notably, this difficulty in tracing non-monetary benefits makes the monitoring of monetary benefits even more important. Professor Thambisetty proposes that such monitoring is only possible if we link international biodiversity law with the patent system. ${ }^{195}$ So far, this theory has been avoided because users would be forced to share

185. Id

186. Id. at 2 .

187. Id. at $6-8$.

188. Id.

189. MuELLER, supra note 27 , at 6 .

190. Id. at 8 .

191. Oldham et al., Dep't for Env't Food \& Rural Aff., Valuing the Deep: Marine Genetic Resources in Areas Beyond National JURISDICTION 152 (2014).

192. Thambisetty, Marine Genetic Resources Beyond National Jurisdictions, supra note 120 .

193. Carlos M. Correa, Access to and Benefit Sharing of Marine Genetic Resources Beyond National Jurisdiction: Developing a New Legally Binding Instrument, 79 South Centre 1, 15 (Sept. 2017).

194. Id.

195. Thambisetty, Marine Genetic Resources Beyond National Jurisdictions, supra note 120. 
monetary benefits. ${ }^{196}$ However, this interlinking is important to note because it shows that patents could be used not only to monitor monetary benefits, but also to increase them. This final section identifies the technical and legal requirements that might hinder such an interlinking.

\section{B. Hindrances to the Interlinking of the Patent System and International Biodiversity Law}

In the years leading up to the recent conferences, academics and experts identified three distinct problems with intellectual property rights and MGRs. ${ }^{197}$ These problems include identification of loopholes within digital sequencing information ("DSI"), disclosure of origin ("DOO") requirements, and corporate control of intellectual properties. ${ }^{198}$ Each of these factors will be examined with particular reference to MGRs, their values, and economic benefits.

\section{Disclosure of origin requirements}

Disclosure is a part of the core rationale of patent law - unless an invention is fully disclosed, the patent granted to the invention is invalid. ${ }^{199}$ Applicants may be required to disclose the invention, method of creation, any prior art, the true inventor, and the legal basis for the entitlement. ${ }^{200}$ However, currently neither the Patent Cooperation Treaty nor any other multilateral intellectual property mandates that countries impose a genetic resource DOO requirement in patent applications. ${ }^{201}$ Currently, such a requirement is solely a matter for national and regional law. ${ }^{202}$

As identified above, the only true indicators of actual benefit accrued from MGRs are products that reach the market. ${ }^{203}$ However, with only the present disclosure requirements in place, it is nearly

196. $I d$.

197. Blasiak et al., supra note 19 , at 1 .

198. Id.

199. WIPO, WIPO Technical Study on Patent Disclosure Requirements Related to Genetic Resources and Traditional Knowledge, Study No. 3, 1, 2 (2004).

200. Id.

201. Margo A. Bagley, Of Disclosure "Straws" and IP System "Camels": Patents, Innovation, and the Disclosure of Origin Requirement, in Protecting Traditional Knowledge: The WiPO Intergovernmental Committee on Intellectual Property and Genetic Resources, Traditional Knowledge and Folklore 1, 1 (Daniel Robinson et al. eds., 2017).

202. Id.

203. OldhAm ET AL., supra note 191, at 165. 
impossible to look at products in the market and trace it back to MGRs. ${ }^{204}$ Strict confidentiality clauses protecting market-related data and a lack of adequate methodological transparency in commercial disclosure have contributed to this impossibility. ${ }^{205}$

The existence of a mandatory DOO requirement is immaterial to patent applications because patent applications are only concerned with the origin of the invention. ${ }^{206}$ However, without such a requirement there is no easy way to ascertain whether the inventors are compliant with the applicable ABS regulations. ${ }^{207}$ Moreover, the benefits that could potentially accrue from this are likely going unmonitored.

Therefore, a mandatory DOO requirement is imperative to the ABS framework, both for the creation of non-monetary benefits by displaying greater methodological transparency and for the monitoring of monetary benefits.

\section{Digital Sequence Information}

With advances in technology, genetic material and data are being deposited into GenBanks in digital form. ${ }^{208}$ This is termed as DSI. ${ }^{209}$ Although there is no single definition, DSI contains information that originates from the analysis of the data contained in a digital file with a precise order of nucleotides, amino acids, or molecular structure of proteins. ${ }^{210}$ DSI is also capable of disclosing more information about genetic make-up, such as the evolutionary process leading to adaptation in the living organisms through DNA barcodes. ${ }^{211}$ At present, DSI, which is available as open-access data, goes unregulated or even unacknowledged by the CBD and Nagoya Protocol. ${ }^{212}$

204. Id.

205. $I d$.

206. See WIPO, supra note 199 , at 72 .

207. Correa, supra note 193, at 15-16.

208. Sarah Laird \& Rachel Wynberg, A Fact Finding and Scoping Study on Digital Sequence Information on Genetic Resources in the Context of the Convention on Biological Diversity and Nagoya Protocol ๆ 12-13 (2018).

209. Id. ๆ 12 .

210. Digital Sequence Information, Ministry of Foreign AfFairs of BRAZIL - EnVIRONMENT Division, https://www.cbd.int/abs/DSIviews/Brazil-DSI.pdf [https://perma.cc/335Z-LWH6].

211. See generally Paul Hebert et al., Biological Identifications Through DNA Barcodes, 270 Proc. Bio. ScI. 313 (2003).

212. Claudio Chiarolla, Intellectual Property Rights and Benefit Sharing from Marine Genetic Resources in Areas Beyond National Jurisdiction: Current Discussions and Regulatory Options, 4 QueEn MARY J. OF INTELl. PROP. 171, 173 (2014). 
A key reason for this relates to the definition of genetic resources under the CBD as being genetic material of actual or potential value, which has been interpreted as "matter." ${ }^{13}$ From this, it follows that the intangible DSI cannot constitute genetic resources as defined by the CBD. ${ }^{214}$ At the time of the formulation of the CBD, ABS was intended to show the application of modern biotechnology by assessing the usefulness of genes and biochemicals, rather than accessing genetic resources. ${ }^{215}$ As technology advanced, it is possible that biotechnological $\mathrm{R} \& \mathrm{D}$ can potentially add a lot of value to the genetic resources. This narrow definition has also led to the obscuration of the true object of ABS: information, whether tangible or intangible. ${ }^{216}$

This means that the user countries do not have to pay provider countries for the benefit just because the information consists of genetic sequence data. ${ }^{217}$ In 2019, Blasiak found that there has been an exponential increase in public databases of DSI. ${ }^{218}$ This in turn has roused the indignation of provider countries as they do not deem the benefit of public accessibility of the data to be enough to give up national patrimony. ${ }^{219}$ Therefore, this exclusion leaves valuable genetic sequences unregulated and contributes to the inefficiency of the ABS framework.

\section{Corporate Control}

One core component of the CHM principle is that all nations must share benefits amongst each other, fairly and equitably. ${ }^{220}$ Frakes has interpreted this to require restraining of profit-making activities of corporate entities. ${ }^{221}$ Therefore, one important measure of an efficient ABS regime for MGRs is if their benefits are shared and the profitmaking activities of corporations are curbed.

213. CBD, supra note 8, at art. 2.

214. International Chamber of Commerce, Digital Sequence Information and the Nagoya Protocol: Submission to the CBD 1, 2 (2017) [hereinafter ICC Paper].

215. Muller, supra note 27 , at 8 .

216. ICC Paper, supra note 214 , at $1-2$.

217. Id. at $3-4$.

218. Blasiak et al., Scientists Should Disclose Origin in Marine Gene Patents, 34 Trends, Ecology \& Evolution 1, 3 (2019) [hereinafter Blasiak 2019].

219. WynBerg \& LAIRD, supra note 208, ๆ 37.

220. Jennifer Frakes, The Common Heritage of Mankind Principle and the Deep Seabed, Outer Space, and Antarctica: Will Developed and Developing Nations Reach a Compromise? 21 WIS. INT'L L. J. 409, 412 (2003).

221. Id. 
Blasiak found that nearly $84 \%$ of MGR patents are owned by companies. ${ }^{22}$ "Public and private universities accounted for another $12 \%$, while entities such as governmental bodies, individuals, hospitals, and non-profit research institutes registered the remaining 4\%." ${ }^{223}$ The world's largest chemical manufacturer, German-based BASF, held nearly $47 \%$ of the patent sequences. ${ }^{24}$ The second and third largest companies were based in Japan and the US, respectively. ${ }^{225}$ Moreover, international patent claims have been made by entities in 30 countries and the EU, while the remaining 165 countries remain unrepresented. ${ }^{226}$

Correa explicitly states that these are, by nature, international public goods; because of this nature, they should not be appropriated under private rights, such as patents, conferred by governments. ${ }^{227}$ It is further agreed that benefits accrued to private commercial concerns should be capped and efforts should be made to ensure that the benefits are shared between users and providers. ${ }^{228}$ Although patents are a timed protection, tying up these inventions for a period of 20 years could majorly hinder scientific progress. ${ }^{229}$

However, given the high costs of marine bioprospecting, ${ }^{230}$ it is highly unlikely that corporations or other users would undertake this long process without the incentive of patents. If a more equitable solution is reached without compromising the incentive to innovate, it could potentially create more benefits that can be shared equitably.

With that, three hindrances to the achievement of an effective ABS framework have been identified. Regarding DSI and DOO, the main argument between proponents and opponents is that inclusion of these requirements would help increase monetary benefits but would also result in the simultaneous increase of legal uncertainty. ${ }^{231}$ Further, the Blasiak's 2019 study leaves the intriguing question of whether patents

222. Blasiak et al., supra note 19 , at 2 .

223. Id.

224. $I d$.

225. Id.

226. Id.

227. Carlos M. Correa, South Centre, Access to and Benefit Sharing of Marine Genetic Resources Beyond National Jurisdiction: Developing a New Legally Binding Instrument 2 (2017).

228. Graham Nicholson, The Common Heritage of Mankind and Mining: An Analysis of the Law as to the High Seas, Outer Space, the Antarctic, and World Heritage, 6 N.Z. J. ENV'T L. 177, 185 (2002).

229. 35 U.S.C. $\S 154($ a)(2).

230. Wynberg, supra note 11, at 409.

231. Blasiak 2019, supra note 218, at 394-95. 
are even capable of providing an effective solution to the problem at hand. ${ }^{232}$

\section{Towards An Effective Solution}

In using patents to maximize benefits by providing more effective monitoring of monetary benefits, three hindrances stand in the way of this goal. These hindrances included the lack of a mandatory DOO requirement, the exclusion of DSI from the definition of genetic material, and the overwhelming corporate control of MGR-based inventions.

Chapter III aims to build on this analysis. First, it will address each of the three hindrances identified earlier. To develop an efficient, as well as effective, solution to the problem posed, it is essential to engage in both a political and academic debate. The subsequent section of this article brings attention to both the arguments put forth by states at the BBNJ and proposed solutions within academic discourse. Then, a novel solution to the problem is proposed - effectively solving the problem of legal status and equitable distribution.

\section{A. Mandatory Disclosure of Origin Requirement}

As identified in the previous chapter, a mandatory DOO requirement should be put in place to monitor compliance with the applicable ABS regime. However, the political opinion surrounding this issue is split. ${ }^{233}$ The user and provider States, generally the Global North and South respectively, disagree on the inclusion of DOO requirements for patent applications. ${ }^{234}$ Those in favor of including this requirement, particularly the Global South, argue that it will reduce the incidence of patents that should not have been granted because the subject matter lacks novelty or is too obvious. ${ }^{235}$ The grant of such erroneous patents can create barriers preventing access to foreign markets for products from provider countries. ${ }^{236}$ On the other hand, user countries have resisted a binding agreement or wanted to employ only defensive measures, such as traditional knowledge databases, to

232. Id.

233. Bonfanti \& Trevisanut, supra note 4 , at 222-23.

234. Id. at $221-22$.

235. World Intell. Prop. Org. [WIPO], Intergovernmental Committee on Intellectual Property and Genetic Resources, Traditional Knowledge and Folklore, ๆ 44, WIPO/GRTKF/IC/27/10 (July 9, 2014).

236. Wallace Feng, Appropriation Without Benefit-Sharing: Origin-ofResource Disclosure Requirements and Enforcement Under TRIPS and the Nagoya Protocol, 18 CHI. J. INT'L L. 245, 252 (2017). 
avoid the grant of erroneous patents and the facilitation of ABS. ${ }^{237}$ They claim that a mandatory genetic resources DOO requirement would be unworkable as it would reduce legal certainty and place too much of a burden on patent applicants, resulting in diminished innovation. ${ }^{238}$ The reasoning of countries on either side stems from their pre-existing national laws. ${ }^{239}$

At the international fora, Council for TRIPS and the Conference of Parties for the CBD discussed these requirements a number of times. ${ }^{240}$ Recognizing the call for DOO requirements, the WTO Secretariat considered the suggestion that it should be made a requirement for the grant of a patent under Article 27.3(b) or Article 29 of TRIPS. ${ }^{241}$ However, the Secretariat thought that these provisions were not intended to further the benefit-sharing objective of the CBD, which instead would be better served by contractual solutions between specific parties. ${ }^{242}$ In the Conference of the Parties VI ("COP-VI") of the CBD, Decision VI/24 on Access and Benefit Sharing as Related to Genetic Resources was adopted, ${ }^{243}$ which encouraged the disclosure of the country of origin per the Bonn Guidelines. ${ }^{244}$ However, at the June 2017 WIPO Intergovernmental Committee, it was proposed that the MGRs found in the ABNJ should be excluded from the mandatory requirement ${ }^{245}$ as an $\mathrm{ABS}$ framework under the $\mathrm{CBD}$ was yet to be

237. Council for Trade-Related Aspects of Intellectual Property Rights, Note by the Secretariat: The Relationship Between the TRIPS Agreement and the Convention on Biological Diversity, ฯ 23, WTO Doc. IP/C/W/368/Rev.1 (Feb. 8, 2006).

238. Blasiak 2019, supra note 218, at 394.

239. See generally Blakeney, Proposals for the International Regulation of Geographical Indications, 4 J. WORLD InTELl. Prop. 629 (2005).

240. Council for Trade-Related Aspects of Intellectual Property Rights, supra note 237, ฯ 60.

241. Id. ๆ 79 .

242. $I d$. 144.

243. Conference of the Parties to the Convention on Biological Diversity, Report of the Sixth Meeting of the Conference of the Parties to the Convention on Biological Diversity, ฯ 342, U.N. Doc. $\mathrm{UNEP} / \mathrm{CBD} / \mathrm{COP} / 6 / 20$ (May 27, 2002).

244. Secretariat of the Convention on Biological Diversity, Bonn Guidelines on ACCESS to Genetic Resources AND FAir And Equitable Sharing of the Benefits Arising out of Their UTILIZATION 7 (2002).

245. Intergovernmental Comm. on Intell. Prop. and Genetic Res., Traditional Knowledge and Folklore, Consolidated Document Relating to Intellectual Property and Genetic Resources, 9-10, WIPO/GRTKF/IC/34/4 (Mar. 15, 2017). 
agreed upon. ${ }^{246}$ The discussion has not progressed much in the two years that have followed. ${ }^{247}$ The fundamental issue that has led to this impasse is the question of whether these legal requirements would enable disclosure as such, or act as an effective prohibition on securing patents if certain preconditions go unmet. ${ }^{248}$

There has been much academic engagement with this fundamental issue. For example, Feng outlines the legal implications of either possibility. ${ }^{249}$ If the requirements were to enable disclosure, then that could be pursued under Article 22 and Article 29 of the TRIPS. ${ }^{250}$ On the other hand, if this requirement had to act as an effective prohibition, then that could be pursued under the Nagoya Protocol which allows for checkpoints. ${ }^{251}$

Conducting a similar analysis, Arnaud-Haond suggests that an effort from the WTO requiring geographic and taxonomic origin of resources associated with a patent under TRIPS would help support the CBD regime, which is not a legally binding instrument. ${ }^{252}$ Similarly, Blakeney proposes that disclosure requirements be included as a condition of patentability to increase its stringency and thereby the benefits of the ABS framework. ${ }^{253}$ Therefore, there seems to be a collective consensus within academia that the present legal requirements of disclosure within the TRIPS can simply be extended to require the DOO requirements. ${ }^{254}$

Given the availability of such a simple legal implication, the lack of political consensus on the matter indicates that the solution for this issue does not lie within patent law. As the instrument and any ABS

246. Aysegul Sirakaya, Balanced Options for Access and Benefit-Sharing: Stakeholder Insights on Provider Country Legislation, 10 FrontiER Plant SCI. 1, 2 (2019).

247. Wend Wendland, "Biopiracy" on the high seas? Countries launch negotiation towards a new international legally binding instrument on marine genetic resources in areas beyond national jurisdiction, INTELL. Prop. WATCH (Dec. 14, 2018) https://www.ipwatch.org/2018/12/14/biopiracy-high-seas-countries-launch-negotiationtowards-new-international-legally-binding-instrument-marine-geneticresources-areas-beyond-national-jurisdiction/[https://perma.cc/CD3KU32Q].

248. Feng, supra note 236, at 259-60.

249. See id. at $252-59$.

250. TRIPS, supra note 33, at art. 22, 29.

251. Nagoya protocol, supra note 15, at art. 17.

252. Sophie Arnaud-Haond, Marine Biodiversity and Gene Patents, 331 SCIENCE 1521, 1522 (2011).

253. See generally Blakeney, supra note 239.

254. See e.g., id.; Sophie Arnaud-Haond et al., Marine Biodiversity and Gene Patents, 331 SCIEnCE 1521 (2011). 
regime it formulates will only be effective if it is signed by user and provider countries, it is advisable to consider an alternate solution.

\section{B. Inclusion of Digital Sequence Information}

As discussed in Section II, open access DSI is excluded from the definition of genetic resources under Article 2 of the CBD. ${ }^{255}$ It was noted that including this within the definition would increase the benefits to the ABS regime because it would require user states to pay provider states for the resources used. ${ }^{256}$ Further, non-monetary benefits would also increase as DSI contains information that would not ordinarily be available by making available tangible genetic material. ${ }^{257}$

However, our understanding of what DSI is still vastly incomplete. A "Scoping Study" on DSI was conducted in January of 2018 by the CBD to gather knowledge on what DSI consists of and the concerns it would trigger if it were included within the convention. ${ }^{258}$ At this nascent stage, there has not been much political engagement on the matter. ${ }^{259}$ So, it would be more appropriate to consult the opinions of industrial stakeholders.

However, industrial stakeholders are vehemently opposed to the inclusion of DSI within the Nagoya Protocol. ${ }^{260}$ The International Chamber of Commerce ("ICC") believes that the availability of DSI encourages innovation through natural product research, stimulates scientific collaboration, and promotes publications. ${ }^{261}$ Such exchange is essential to achieve the objectives defined in Article 12 of the CBD, namely to promote and cooperate in scientific advances, and to develop programs for scientific and technical education, among others. ${ }^{262}$ On a similar vein, the League of European Universities ("LERU") argues that

255. See CBD, supra note 8, at art. 2.

256. See generally Jon Ambler et al., Including Digital Sequence Data in the Nagoya Protocol Can Promote Data Sharing, 39 World Trends IN Biotechnology (2021); Aysegul Sirakaya, Balanced Options for Access and Benefit-Sharing: Stakeholder Insights on Provider Country Legislation, 10 Frontiers in Plant Science 1 (2019).

257. See generally Margo Bagley et al., Convention on Biological Diversity, Fact-finding Study on How Domestic Measures Address Benefit-sharing Arising from Commercial and Non-commercial Use of Digital Sequence Information on Genetic Resources and Address the Use of Digital Sequence Information on Genetic Resources for Research and Development, U.N. Doc. CBD/DSI/AHTEG/2020/1/5 (Jan. 29, 2020).

258. See WynBerg \& LAIRD, supra note 208.

259. See, e.g., Ambler, supra note 256; Sirakaya, supra note 256.

260. Nohyoung Park, How to Approach the Issue of Digital Sequence Information: Focusing on the AHTEG, 21 ASIAN BUS. LAW. 15, 25 (2018).

261. ICC Paper, supra note 214, at 2.

262. See CBD, supra note 8 , at art. 12 . 
requiring the inclusion of DSI will add to the complexity of the Nagoya Protocol, which is already burdensome for universities. ${ }^{263}$ Further, universities conduct both commercial and non-commercial research; as the Nagoya Protocol does not make a distinction between the two, ${ }^{264}$ similar limitations will apply to purely curiosity-driven research and thus curb innovation.

On the other hand, academics such as Jefferson and Thambisetty have argued that, by requiring the inclusion of open-access genetic material, the material would be termed "prior art." 265 This would then lead to the failure of fulfilling the novelty requirement of patentability. ${ }^{266}$ Therefore, such material would be easily patentable by others such as corporate entities. Without the protection of DSI being treated as genetic resources under the Nagoya Protocol, there is a very real possibility that it will end up in corporate control. ${ }^{267}$

Although the corporate control of such DSI is worrisome, the valid and vehement opposition to its inclusion within the Nagoya Protocol by stakeholders demonstrates that regulation of open-access patents is not the solution.

\section{Overwhelming Corporate Control}

The overwhelming corporate control of inventions derived from MGRs was unearthed by a study from Blasiak in 2017. ${ }^{268}$ Further, as discussed above, publicly available databases have led academics to fear that corporate entities could patent this open access data. ${ }^{269}$

263. League of European Research Universities, Inclusion of Digital Sequence Information in the Nagoya Protocol Would Significantly ImPEDE University RESEARCH 5 https://www.leru.org/files/LERU-Nagoya-Statement-November2018.pdf [https://perma.cc/TF9W-LQB8].

264. See generally Nagoya Protocol, supra note 15.

265. Osmat Jefferson et al. Public Disclosure of Biological Sequences in Global Patent Practice' 2015 World Patent Information, 43 World PATENT Information 12, 16 (2015); see also Thambisetty, Marine Genetic Resources Beyond National Jurisdictions, supra note 120, at 8.

266. Jefferson et al. supra note 265, at 21-22.

267. Thambisetty, Marine Genetic Resources Beyond National Jurisdictions, supra note 120 , at 6 .

268. See generally Blasiak et al., supra note 19; see also RoBERT BlASIAK et al., Climate Change and Marine Fisheries:

Least Developed Countries Top Global Index of Vulnerability (2017).

269. See generally Jefferson et al. supra note 265; Thambisetty, Marine Genetic Resources Beyond National Jurisdictions, supra note 120, at 6. 
An interesting point put forth by Thambisetty is that corporations tend to have low thresholds for legal uncertainty. ${ }^{270}$ Legal rights to MGRs within the ABNJ tend to be far more certain as they remain unregulated by the Nagoya Protocol. ${ }^{271}$ This certainty makes these resources far more viable avenues of investment to corporations. ${ }^{272}$

If this led to the grant of many patents, as it is likely to, it will amount to the fragmentation of rights and the private appropriation of an area that is to be treated as CHM. Even if the CHM principle does not apply to these resources, academics believe that appropriation must still be avoided. ${ }^{273}$ The fragmentation of rights could lead to the "tragedy of the anti-commons" or patent thickets where the private appropriation of biotechnological genes could lead to the underutilization of the resources. ${ }^{274}$ This could hinder innovation rather than promote it. ${ }^{275}$ Moreover, scientific innovations developed from these patented genetic material will almost certainly be inaccessible to poorer populations. For this reason privately owned patents on genetic material and information is not compatible with the idea of good governance of MGR from ABNJ nor is it in the best interests of all mankind.

Given the numerous incentives for patents on genetic resources, ${ }^{276}$ and the limited number of entities who have the capacity to prospect on the high seas, ${ }^{277}$ this is a problem that needs to be resolved urgently. However, due to the exclusive rights granted by patents, ${ }^{278}$ it might be wise to consider an alternative approach to reach a timely and viable solution.

Therefore, none of the three hindrances to the achievement of framing an efficient ABS regime can be effectively overcome through

270. Thambisetty, Marine Genetic Resources Beyond National Jurisdictions, supra note 120 , at 9 .

271. Id.

272. Id. at 6 .

273. Correa, supra note 193, at 2.

274. Michael Heller, Tragedy of the Anticommons: Property in the Transition from Marx to Markets, 111 HARV. L. REV. 622 (1998).

275. Louise de la Fayette, A New Regime for the Conservation and Sustainable Use of Marine Biodiversity and Genetic Resources beyond the Limits of National Jurisdiction, 24 InT'L J. MARINe \& CoAstal L. 221, 278 (2009).

276. See e.g., Itsuki Shimbo et al., Patent Protection and Access to Genetic Resources, 26 Nature Biotechnology 645 (2008).

277. Id. at 646 .

278. General Information Concerning Patents, U.S. Patent \& Trademark OFF. (Oct. 2015), https://www.uspto.gov/patents/basics\#heading-1 [https://perma.cc/9699-QGYV]. 
the patent system. Although academics agree that the imposition of a mandatory DOO requirement would naturally extend from the existing disclosure requirements, there is a lack of political consensus in this regard. ${ }^{279}$ Second, regarding the inclusion of DSI within the Nagoya Protocol, this would lead to the realization of greater benefits by requiring users to pay providers for access to information. But stakeholders are opposed to this proposal because it would increase legal uncertainty and create a more tedious ABS regime. ${ }^{280}$ Finally, the very nature of patents gives rise to the issue of overwhelming corporate control. Keeping this in mind, in the final section of this paper I propose a possible alternative solution.

\section{Alternative Solution}

Although patents may be able to maximize or monitor monetary benefits, they may not be the most effective solution given the lack of political and stakeholder consensus. Academics agree that, regardless of MGRs within ABNJ being classified as CHM, the area constitutes a public domain whose management can only be considered effective when not privately appropriated by any one party. ${ }^{281}$ "Rather, the system should be based on cooperative actions and accessibility to the outcomes of innovation." 282

One thing that the solutions above failed to consider is the political tensions and what the most realistic option would be. The deadlocks identified in Chapter II will not effectively be solved by the solutions analyzed in Section III because States, who have been identified as the main stakeholders at the BBNJ, ${ }^{283}$ will still negotiate with their vested interests in mind. These must be considered alongside free-market principles so that the 1994 Implementation Agreement ("Implementation Agreement") is signed by developing as well as

279. See Michael D. Guttentag, An Argument for Imposing Disclosure Requirements on Public Companies, 32 Fla. ST. UnIV. L. REV. 124, 12425 (2004).

280. See generally Elizabeth J. Karger \& Amber Hartman Scholz, DSI, the Nagoya Protocol, and Stakeholders' Concerns, 29 TRENDS IN BiotechNology 110 (2021).

281. See e.g., Shimbo et al., supra note 276, at 645 .

282. Carlos Correa, supra note 193, at 20.

283. See generally Intergovernmental Conference on an International Legally Binding Instrument Under the United Nations Convention on the Law of the Sea on the Conservation and Sustainable Use of Marine Biological Diversity of Areas Beyond National Jurisdiction, U.N. Doc. A/CONF.232/3019/1 (Dec. 3, 2018). 
developed states. If not, then a similar situation that brought the Implementation Agreement will be reached. ${ }^{284}$

However, an emerging new method of management of the public domain has recently emerged with free market principles at its heart. ${ }^{285}$ This is the principle termed "nondominium" 286 and it requires due consideration as an effective alternative solution.

\section{Application of Nondominium to ABNJ}

Nondominium was coined by Chris Cook as a concept much like regional stewardship or trusteeship. ${ }^{287}$ As a principle, nondominium is an agreement which brings the stakeholders together - either jointly or collectively - to hold land in common, but also enables them severally and individually to share the rights and obligations as they may consensually agree. ${ }^{288}$ It places economic development at its heart. ${ }^{289}$

Simply put, the user of the land pays a rental in money or kind and a proportion of this flow of value is allocated to a group of stakeholders that introduce the occupiers and investors, among other things, as a service. ${ }^{290}$ In designing the regime, the stakeholder's interests are in line with that of any investors who participate within the system. ${ }^{291}$ The stakeholders are not themselves entitled to any dominant rights; however, they possess certain veto rights within the agreement. ${ }^{292}$ Essentially this results in "a cooperative of cooperatives," in the words of Cook. ${ }^{293}$ Although the occupier, investor and manager can all change, the land in itself can never be bought or sold and will remain in perpetuity as a nondominium. ${ }^{294}$

284. Brown, 'Neither Necessary nor Prudent at this Stage': The Regime of Seabed Mining and its Impact on the Universality of the UN Convention on the Law of the Sea, 17 MARINE POL'y 2, 81, 82 (1993).

285. Mandeep Bhandal, Submission by Chris Cook to the Land Reform Review Group, ResiliBlog, https://blogs.ucl.ac.uk/resilience/2013/01/16/submission-by-chris-cookto-the-land-reform-review-group/ [https://perma.cc/LKM4-DZV9].

286. $I d$.

287. $I d$.

288. Id.

289. $I d$.

290. $I d$.

291. $I d$.

292. Id.

293. Id.

294. Id. 
This principle was applied to the ocean and its resources by Laister and Faizer. ${ }^{295}$ According to Laister and Faizer, a trustee for the CHM would represent a group of beneficiaries and oversee the legal operation of the common area. ${ }^{296}$ Meanwhile, a manager would also be appointed, to help them identify opportunities for advancement of the common pool of resources per a transparent formula for revenue sharing. Each representative has the right to veto a resource development proposal put forth.

When a formula is agreed upon, recognizing the needed inputs and the overall revenue sharing, the manager will arrange to open tenders to make potential investors and occupiers meet. This solution will ensure the maximizing of the economic value of the MGRs within the ABNJ. All the while, such tenders would remain neutral with no nationality or domicile and the revenue from ensuing activities would be distributed on a previously agreed basis. The manager also handles those who are noncompliant. This allows for an efficient dispute resolution process. In this manner, this framework as set out by the nondominium principle conforms to the international law requirements that no country or political groups could dominate. ${ }^{297}$

\section{Benefits over Current Regime}

The legal framework considered by this paper so far dealt with creation of an ABS framework regarding the patent system. Thus, this paper only considers the maximizing of the economic value and the incentivizing of innovation.

The inventions derived from MGRs can be commissioned through tenders. To create greater economic value, this approach would help provide incentives at an earlier stage of the bioprospecting process as users pay rent and investors would be privy to the terms agreed upon. Further, this approach aids the advancement of science and the common resources while also incentivizing innovations. It allows the beneficiaries to enlist the help of technologically advanced countries to create an invention for which a need was felt. In doing so, it does not tie up genetic material upstream as the tenders remain neutral and benefits accrued will be shared in a previously agreed manner. This could be an effective way to deal with the problem of overwhelming

295. Valnora Leister \& Mark Frazier, From Local to Global Commons: Applying Ostrom's Key Principles for Sustainable Governance, EARTH SYSTEM Governance 18, http://www.earthsystemgovernance.org/lund2012/LC2012-paper94.pdf [https://perma.cc/WF5U-Q92E].

296. Id.

297. See Nico Krisch, International Law in Times of Hegemony: Unequal Power and the Shaping of the International Legal Order, 16 EUR. J. INT'L L. 370 (2005). 
corporate control over patents. Rather than create exclusive rights, corporations would be able to negotiate the benefit-sharing mechanism.

Further, it could be argued that the debates surrounding the DOO and DSI requirements, which had come to a standstill due to clashing interests of state parties, ${ }^{298}$ could now move forward. The DOO requirement will no longer be an issue as the vested interests of the States will have to be negotiated between the concerned parties at the time of the conclusion of the tender. Similarly, regarding the DSI requirement, the added complexity and uncertainty surrounding the already burdensome Nagoya Protoco ${ }^{299}$ will no longer exist.

Therefore, the nondominium principle could potentially pave the way to incentivize user countries to innovate without private appropriation of rights through patents. Further, it also helps maximize economic value and share the resources in an equitable manner. Finally, the nondominium principle formulates an effective and probable solution as it considers the existing political and stakeholder conflicts. ${ }^{300}$

\section{CONClusion}

With advancement in technology, the context surrounding the UNCLOS, the CBD and the TRIPS has changed. Sections I and II identified the regulatory gap caused by the bioprospecting of MGRs within ABNJ. Moreover, when significant contextual transformations take place, new norms emerge, old norms expire, and their interpretations shift. Discussing the uncertainty surrounding the legal status of the MGRs within the ABNJ in Section I, taking a normative approach to the application of Article 31 of the VCLT, it is possible that the old interpretation could be shifted to cover the gap in the law and thus achieve the objectives of the development agenda.

Section III addressed the regulatory gap within the CBD and the possible relationship between the TRIPS and the CBD. The patentability of genetic material was briefly considered, and the importance of human intervention was emphasized. Then, the chapter continued by discussing three hindrances when linking the patent system to the ABS framework. These hindrances were the lack of a mandatory DOO requirement, the exclusion of DSI from the definition of genetic material, and the overwhelming corporate control of MGRbased inventions. Discussing the political and academic misgivings to these three hindrances, Chapter III identified the deadlock that the discussions reached regarding each of these points. Although academics agreed that the imposition of a mandatory DOO requirement would naturally extend from the existing disclosure requirements, there is a

298. See generally Chiarolla, supra note 212.

299. See Nagoya protocol, supra note 15.

300. Bhandal, supra note 285. 
lack of political consensus. ${ }^{301}$ Second, regarding the inclusion of DSI within the Nagoya Protocol, although this would lead to the realization of greater benefits by requiring users to pay providers for access to information, stakeholders are vehemently opposed to this proposal as it would increase the legal uncertainty and create a more tedious ABS regime. ${ }^{302}$ Finally, the issue of overwhelming corporate control was caused by the very nature of patents, which grants exclusive rights. ${ }^{303}$ As it emerged that the solution does not lie within the patent system, it became clear that the nondominium principle is the most effective and probable solution.

The nondominium principle would allow for the management of the public domain while carrying the free market principles at its heart. This management method would effectively create a solution for the three hindrances identified above. Moreover, it would propose an equitable distribution of resources while maximizing economic value for the countries of the Global North and the South. Most importantly, it could potentially pave the way to incentivize user countries to innovate without private appropriation of rights through patent. However, it remains to be seen whether stakeholders prioritize innovation and equitable distribution over private appropriation and profit.

301. See e.g., Chiarolla, supra note 212, at 179.

302. See id. at 178 .

303. General Information Concerning Patents, supra note 278. 